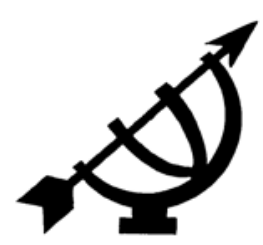

\title{
Reflections on a Christian view of human communication
}

\author{
H.A. van Belle \\ Department of Psychology \\ The Kings University College \\ Edmonton \\ CANADA \\ E-mail: harryvanbelle@hotmail.com
}

\section{Abstract \\ Reflections on a Christian view of human communication}

This article defines human communication as community building and describes the various functions of communication in life. It argues that a number of other human activities are presupposed in communication without which communication would not be possible. These activities are its inherent functions. Community building is described as the authentic function of communication. Without it communication would not be what it is. Lastly, there are several social activities that depend on communication for their existence. These are what communication is for. Such functions form the adherent functions of communication. Next the article describes a set of norms or criteria for distinguishing good communication from bad. Then follows a description of some models of communication found in the literature. These are seen as less than full descriptions of actual human communication. A few of these models reduce communication to one or more of its inherent functions. One honours the authentic function but none of them do justice to the adherent functions of communication. In addition, the article briefly describes and evaluates mass media communication. Because of its monological nature this communication can only produce one-way messages from sender to receiver. It thus gives the sender an unfair advantage of influence over the receiver. Dialogical communication remedies that problem and is to be preferred because in it the influence is mutual between the sender and the receiver of a message. However, it fails to account for the influence of such communication on third parties 
not involved in the dialogical relationship. The article, therefore, favours what it calls a triological form of communicating. In closing the article briefly describes social networking as the latest form of human communication.

\section{Opsomming}

\section{Reflektering op 'n Christelike uitkyk op menslike kommunikasie}

Hierdie artikel definieer menslike kommunikasie as gemeenskapsopbouing en beskryf verskeie funksies van kommunikasie. Daar word geargumenteer dat 'n aantal ander menslike aktiwiteite in kommunikasie vooronderstel word waarsonder kommunikasie nie moontlik sou wees nie. Hierdie aktiwiteite is inherente funksies. Gemeenskapsopbouing word beskryf as die outentieke funksie van kommunikasie. Daarsonder sou kommunikasie nie kon wees wat dit is nie. Laastens is daar ook verskeie sosiale aktiwiteite wat van kommunikasie afhanklik is vir hulle voortbestaan. Dit is waarvoor kommunikasie daar is. Sodanige funksies vorm die adherente funksies van kommunikasie. Vervolgens beskryf die artikel 'n stel norme of kriteria om goeie kommunikasie van slegte kommunikasie te onderskei. Daarna volg 'n verduideliking van sommige van die kommunikasiemodelle wat in die literatuur gevind kan word. Dit is egter nie volledige beskrywings van werklike menslike kommunikasie nie. 'n Paar van hierdie modelle reduseer kommunikasie tot een of meer van die inherente funksies van kommunikasie. Een erken die outentieke funksie, maar geeneen laat reg geskied aan die adherente funksies van kommunikasie nie. Verder beskryf en evalueer die artikel kortliks massamediakommunikasie. As gevolg van die monologiese aard van hierdie kommunikasie kan slegs eenrigtingboodskappe vanaf die sender na die ontvanger gestuur word. Dus word 'n onregverdige voordeel aan die sender verleen ten opsigte van die beïnvloeding van die ontvanger. Dialogiese kommunikasie dien as oplossing vir die genoemde probleem en word daarom verkies, omdat hiermee die invloed tussen sender en ontvanger wedersyds gelyk is. Hierdie model hou egter nie rekening met die invloed daarvan op 'n derde party wat nie direk by die dialogiese verhouding betrokke is nie. Hierdie artikel verkies dus wat genoem word 'n triologiese vorm van kommunikasie. Ten slotte beskryf die artikel kortliks sosiale netwerking as die mees onlangste vorm van menslike kommunikasie.

\section{Reflection on the nature of human communication}

This article is a reflection on communication only. It has the character of thinking out loud and is offered in appreciation to Professor Dr. Bennie van der Walt who has done so much to promote cross- 
cultural communication in Africa. The article utilises the philosophical framework developed by Dooyeweerd (1953), and especially his idea that reality has a modal horizon that allows our theoretical analysis to conceptualise a multiplicity of unique, mutually irreducible, yet interconnected aspects. Within this general philosophical framework I am very much in debt to the insights of the late P.A. Verburg, who during his life was professor of Linguistics at the State University of Groningen, the Netherlands.

This article deals exclusively with communication as a human activity and begins by asking what human communication is. To my understanding, communication is the activity of community building. Another way of saying this is that communication includes every human activity that fosters our communality, as distinguished from our individuality. The work of communication is the work of communification (Latin: ficere: to make). In communication people seek to have things in common. The communicative side of life is the human drive of individuals to become one with other individuals. The process of communication is sharing, and its product is multi-unity.

Communication is the human activity in which two or more communicators express themselves to one another with the intent of sharing themselves with one another. Communication is expression that fosters communality. The activity of communication is a necessary condition for the existence of interhuman relations and for the existence of communities, including social entities such as friendship, marriage, family, organisations, et cetera, thus loosely what we mean when we indicate society. The fostering and maintenance of communality or society requires the activity of communication. Communication is the human activity by two or more co-communicators of forming and maintaining social entities or groupings such as interhuman relationships and communities.

Both culture and society are dependent on human communication. They are the products of human communication in the sense that culture and society consist of a set of rules and conventions which people formulate, maintain and change in the course of communicating with one another. Culture and society would cease to exist the moment people would stop communicating with one another.

Habermas (1981), a prominent hermeneutic philosopher, has written extensively on how social rules and conventions come into being, how they are maintained and how they can be changed. He argues that rules and conventions originate in, and are maintained by dialogue, or the activity of communication. His main point is that if 
dialogue can call rules and conventions into being and can maintain them, it can also change them. Following his insight we can therefore say that communication offers us the opportunity to call good social conventions into being and to maintain them, while at the same time it gives us the ability to edit bad conventions out of existence.

\section{Reflection on how communication functions in human life}

Another way to define communication is to describe how it functions in human life or how it relates to other human activities. To do that there must, first of all, be distinguished between "functions of" and "functions for" communication.

Many human activities are functions of communication. Conversely communication itself functions as part of many other human activities; it is for these other activities. Another way of saying this is to say that communication has an authentic function, inherent functions and adherent functions (Verburg,1951; 1965; 1971; see Figure 1).

Figure 1: Communication functions in human life as ...

\begin{tabular}{|l|l|l|}
\hline Concrete things/activities & Qualifying function & (Verburg) \\
\hline $\begin{array}{l}\text { Religious institutions } \\
\text { (church, party, ideological } \\
\text { camp) }\end{array}$ & Faith keeping & \\
\hline Marriage/family & Caring & $\begin{array}{l}\text { Adherent } \\
\text { function (for) }\end{array}$ \\
\hline Public relations/government & Political & \\
\hline $\begin{array}{l}\text { Industrial organizations } \\
\text { for example within }\end{array}$ & Economic & \\
\hline $\begin{array}{l}\text { Socio-cultural institutions } \\
\text { (of any kind) } \\
\text { occurs within }\end{array}$ & Social & \\
\hline $\begin{array}{l}\text { Communication } \\
\text { (forming of communities) }\end{array}$ & Communicative & $\begin{array}{l}\text { Authentic } \\
\text { function (is) }\end{array}$ \\
\hline Referring/expression & Lingual & \\
\hline $\begin{array}{l}\text { Interpretation/judgment } \\
\text { thinking/imagining } \\
\text { awareness/memory }\end{array}$ & Intellectual & \\
\hline
\end{tabular}




\begin{tabular}{|l|l|l|}
\hline $\begin{array}{l}\text { Perceptual forming } \\
\text { emotional reaction } \\
\text { sensation/affect } \\
\text { (who are capable of) }\end{array}$ & $\begin{array}{l}\text { Inherent function } \\
\text { (of })\end{array}$ \\
\hline $\begin{array}{l}\text { by 2 (or more) Organisms } \\
\text { (communication is embodied) }\end{array}$ & Biological & \\
\hline $\begin{array}{l}\text { via a Physical medium } \\
\text { (excludes telepathic com- } \\
\text { munication) }\end{array}$ & Physical & \\
\hline $\begin{array}{l}\text { Between 2 (or more) persons } \\
\text { (excludes intra personal } \\
\text { communication) }\end{array}$ & Numerical & \\
\hline
\end{tabular}

\subsection{Authentic function of communication}

The question about the unique function of communication in human life is answered by describing its authentic function. This is done in section 1 above.

\subsection{Inherent functions of communications}

A second way of describing communication is to analyse what communication entails, what other human activities are implied in communication, and what its inherent functions are. What do we presuppose when we say that people communicate with one another? We assume the existence of at least two individuals who are numerically distinct and who both have the capacity to communicate with one another. This formulation implies that intrapersonal communication ("talking to yourself") is an analogous way of talking about communication only, i.e. it looks like it, but is not communication.

When we say that people communicate we further assume that people interact with one another via some physical medium or another. People must in some way or another be physically in contact with each other to communicate. This formulation excludes telepathic communication. Thirdly we assume that communication is always "embodied". It presupposes the presence of at least two distinct organisms with nervous systems which function with a minimum of adequacy. Thus, my formulation entails that disembodied communication is no more possible than disembodied thought.

Next, we presuppose that human beings who communicate are capable of psychological functioning. That is to say, the definition entails that they must be capable of sensation, i.e. they must be in some kind of psychological contact. They must also be capable of emotional reaction and perception to be able to communicate. 
Furthermore, we presuppose that communicators are capable of intellectual functioning, i.e. that they have such cognitive abilities as awareness and memory, thinking and imagining as well as interpretation, judgment and valuation.

Finally, communication presupposes the capacity for lingual functioning, i.e. the capacity for "symbolic objectification". This is the ability of communicators to refer to the concrete entities and events of their world in terms of symbols such as words, gestures, signs and images. It also includes the ability to express these symbols.

A less exact way of describing what communication entails is to say that it presupposes at least two organisms, who are in physical contact with one another, who are stimulated, who sense, perceive, are aware, who remember, who think, who judge and who speak. All of the human characteristics described above are presupposed in human communication. However, all of these together do not yet describe communication. What must be added is communication itself, these activities must be done with the intent of forming society.

\subsection{Adherent functions of communications}

Until now, the human functions involved in communication have been described, including its own authentic function in human life, without which human life would not be what it is. In short, the human activities inherent in communication have been described as well as which human activity qualifies it, i.e. what human activity uniquely describes what it is. The adherent functions of communication refer to those human activities that are made possible by communication. They are what communication is for. They are those human functions of which communication is itself an inherent function. Adherent functions imply communication. Without communication they would not be possible. Typical examples of the adherent functions of communication would be its inherent functioning in social activity, in commerce, in the (fine) arts, in the justice system, in relationships and communities formed to practice neighbourly love and in relationships and communities in which human beings confess an ideology or a religion. The Greek word for confession, (homologia) means "saying the same thing as". This suggests that confession has a built-in urge to form community.

The human activities which form the adherent functions of communication are not themselves communicative activities, but communication is embedded in these activities. People never just communicate. They always communicate as part of, and as expression of 
their being with one another, working together, dealing justly with one another, loving one another and sharing their beliefs with one another, et cetera.

\section{Norms for judging the process and products of communication}

How do we know whether a given communication process is good or bad? The first thing to note is that people do regularly distinguish between good and bad communication. We say, quoting the Bible, that bad communication or conversation makes for a bad character. We talk about the negative influence of peer pressure, about the media making inroads into the church, and into family life. We say that advertising on television creates a mass consumer mentality, or that it fosters common denominator tastes. We speak of negotiating in bad faith and of a breakdown in communication. We note that sometimes people talk past one another, and we speak of one-sided conversations, of people fighting with one another without regard for its effect on innocent third parties, et cetera. We consider many forms of actual communication that are bad for people's lives, but how do we judge these activities in communication terms? In what way are these bad forms of communication? To make this judgement we must have norms, or criteria for communication. Where do we get them? At this point I can make some suggestions only. These need to be worked out in more detail to be useful for judging forms of communication.

For example, we can use biblical norms. I can think of three biblical metaphors that can function as norms. There is first of all the metaphor of the Christian community as the "body of Christ", which forbids all power tripping forms of communication. In the body of Christ we are called to recognise only one person as the authority, Christ the head of the body, and to treat one another equally as members of that body. According to this metaphor good communication is egalitarian and inclusive.

The second biblical metaphor is confession or homologia, the root meaning of which is "saying the same thing". I believe this metaphor points to the fact that, whereas bad communication often divides, good communication promotes unity.

The last metaphor is one which St. Paul often uses at the beginning of his letters, when he writes to his readers, "I urge you", or "I plead with you", or "I admonish you", or "I exhort you ...". These are all translation of the one Greek word, parakalein, which literally means 
"to call near". It is St. Paul's overriding passion to call his readers near(er) to Christ, based on his conviction that in Christ all things, including humanity, hang together. Thus, for St. Paul, good communication ultimately can only be Christ-centered communication.

We do not need to use religious language to norm communication. We can also use creational norms. We can distinguish between good and bad communication by distinguishing between community and uniformity as the result of communication. Good communication recognises the importance of individual differences. The result of communication should be a unity in diversity, not sameness. The product should be com-unity rather than uni-formity.

This was an example of a creational norm at the group level of communication. At the level of (inter-)individual communication the norm for distinguishing good from bad communication could be the distinction between authenticity and manipulation. This norm dictates that communication should be genuine, without dissimulation. It should not be aimed at getting the better of one's communication partner.

Finally, to distinguish good communication from bad we can utilise norms related to the direction of the flow of information in communication. In monological communication one person or party sends a message and the other receives it. The danger of this form of communication is that the sender may have undue influence over the receiver of the message. This is why some people (e.g. Buber, 1955 ; 1958) have argued that good communication should be dialogical. Dialogical communication is a form of communication in which both parties send and receive messages. In this form of communication it is more likely that the influence between the communicators is mutual. However, even dialogical communication cannot avoid adversely affecting certain individuals. In many forms of dialogue there are third parties, who are not part of the dialogue but whose lives may be profoundly affected by the dialogue. This is why I believe that all forms of communication should be triological. That is, the conversations two parties may have or cease to have, the alliances they make or break; or the decisions they agree on in the course of their dialogue should not hurt third parties who are not part of their conversation or alliance. Obvious examples of situations where this is a concern are parents divorcing, people gossiping, and collusion in business deals. These are some of the communication norms that I believe can help to distinguish good communication from bad. 


\section{Norms for judging models of communication}

There are many descriptions of communication in the literature. Using these as models to describe communication can provide us with insight. They can also lead us astray. Are these models adequate descriptions of what actually goes on when human beings communicate? How do we judge? I believe we can judge their adequacy by using the authentic, inherent and adherent functions of communication as norms or criteria. When we do that, we note that perhaps all of these models are reductionistic descriptions of communication. They tend to define communication in terms of one of its inherent functions. Let's have a look at them.

\subsection{Transmission model of communication}

The transmission model of communication (Carey, 1989) is the oldest and probably the most reductionistic. It describes the process of communication as a (physical) signal emission-detection process. In this view communication is like the operation of a telegraph, or telephone system. This model is of historical interest only. As a model of communication it is not used any more.

\subsection{Information processing model of communication}

What has taken its place is an information processing model (Shanon \& Weaver, 1949). It is by far the most popular model today. In essence this model is a computer analogue, in which a sender encodes a message and sends it via a channel, where at the other end a receiver decodes it.

\subsection{Interaction model of communication}

Next is the interaction model of communication (Wiener, 1950; 1961). This model recognises that in communication the receiver influences the sender via feedback. The theory goes as follows: A sends a message via a channel to $B$. However, $B$ does not receive the message as it was sent, due to noise in the channel. $B$ feeds back his imperfect reception of the message to $A$, whereupon $A$ modifies the message taking in account the feedback he receives from $B$, until $B$ gets the message as it is sent by $A$. When this happens, the noise in the channel is said to be reduced to zero. This is the model of the philosophy of Cybernetics or Systems theory. This model also holds that communications between people and people, between people and machines, and between machines and machines are fully interchangeable. Norbert Wiener, the father of 
Cybernetics theory states (Matson, 1967:16): "When I give an order to a machine, the situation is not essentially different from when I give an order to a person." It will be clear that this view reduces human communication to a mechanical process that is done better by machines. The critique of this view by Jacques Barzun, (Matson, 1967:105) another communication theorist, is, therefore apt. He wrote: "Greater love of the machine cannot be conceived than that man should think his own mind inferior to the thing he has made."

\subsection{Transaction model of communication}

There is also a transaction model of communication (Matson, 1967: 209). This model recognises that there is a mutual influence between the sender and the receiver as the interaction model has noted. It adds to this that the influence between the sender and the receiver goes on simultaneously and not successively.

\subsection{Interpersonal relations model of communication}

The interpersonal relations (IPR) model (Rogers, 1961) recognises that both the sender and the receiver in human communication are persons or subjects. This theory argues that factors inside the communicators and how they view their worlds decisively, determine the communication process. Communication is essentially an interview, an exchange of viewpoints and no more. The emphasis here is on the personhood of the communicators. This model stresses that people who communicate have something to say.

\subsection{Dialogue model of communication}

The dialogue model of communication (Buber, 1955; 1958) emphasises what goes on between the communicators. Like the transaction model it holds that communication is a relation, but unlike the transaction model, it stresses that communication is a relation between subjects or persons. Communication is an intersubjectivity, an activity of relating in which the communicators participate.

\section{Critique of these models of communication: reductionism}

It seems to me that all of these models are reductionistic descriptions, and therefore inadequate descriptions of actual human communication. This reductionism is clear in the case of the information processing and the transmission models. These reduce communication to its machine analogue. Their fundamental error is that they do 
not recognise that machines only communicate when there is someone at either end of the process who has something to say or to understand.

This fact is more clearly noted in the interaction and the transaction models, and it is especially stressed in the IPR model, where the emphasis is on two persons expressing themselves. However, even these models are reductionistic. They cannot explain why people would want to express themselves or have something to say. The authentic function of communication explains that people express themselves to one another in order to form or to modify communities. By not including the authentic function of communication in their model the interaction, the transaction and the IPR models reduce communication to its inherent functions.

What about the dialogue model? With its emphasis on intersubjectivity it does seem to include the authentic function in its description. It too is reductionistic however, because it cannot account for the different kinds of communication that exist. It does not explain why people form communities, because it does not include the adherent functions of communication into its model. People communicate in order to work together, run a country together, to show neighbourly love to one another, to keep the faith together. Since these different functions occur in different institutions, they require different kinds of communication. The way people communicate in marriage, for instance, is quite different from the way they communicate at work - or at least the way they communicate should be different.

To summarise: the transmission and information processing models reduce communication to some of its inherent functions. The interaction, the transaction and the IPR models reduce communication to all of its inherent functions. And the dialogue model reduces communication to its inherent functions plus its authentic function. Consequently, none of the current models gives a full description of communication as it actually occurs in human life.

\section{Mass media communication}

A definition of mass communication can be as follows:

Mass communication is any communication that uses graphic, electronic, speech, print or nonverbal devices designed to communicate with large groups of people who are not immediately present. Mass communication is mediated, rather 
than face to face communication. Its chief aim is to create, gather and to deliver messages, to express worldviews and to interpret data in terms of these worldviews. The role of mass media communication is to promote communality and the product of this process is a shared outlook on life.

In distinction from face to face communication, mediated mass communication lacks the personal presence of co-communicators. It consists of one, or a few communicators sending messages to many, to a mass. It is, therefore, monological and it creates an audience. It requires a specific type of message. It emits a climax type of message, that is, it overdramatises, it sensationalises, and it stylises the message content. It also requires audience analysis. That is to say, it requires an analysis of the needs, the wants and the preferences of a variable audience. It gears its messages to these needs and produces common denominator values.

Mass communication is necessarily dependent on technology. This dependence imposes its own inherent restrictions on mass communication. These restrictions entail that this medium can only communicate by means of news flashes or news clips, and by headlines, maximum impact images, the ad jingles, and disconnected discourse with multiple repetitions. All these discourage a leisurely examination of the message. Mass communication controls much of the flow and content of the information it presents. Therefore, in distinction from other forms of communication, it has a major social impact on its audience.

Via its products, such as advertisements and programs, via its technologies, such as television sets, radios, stereo sets, records, CDs, and computers, and via its popular culture manifested in hits, films, designer clothes, hair styles, fashion accessories, fads, life styles, et cetera it defines our culture often as a consumer culture. Furthermore, by its selective coverage of social problems it sets the agenda for our society. No individual or group can place an issue on the public agenda without media coverage. For all these reasons the mass communication media function as gatekeepers of public opinion. Mass communication media inform and train us and, therefore, educate us. They also define what teaching and learning is. They shape our beliefs, our values, our view of others, our view of ourselves and our view of society as a whole. They define social conflicts and how these should be resolved.

Mass communication media unduly influence the other social institutions of our lives - those of family, marriage, government, business 
and the way people communicate in those institutions. Mass communication media influence family conversation, and political behaviour due to coverage of government figures. It influences the way business is run by the public attitudes it constructs.

Finally, the mass communication media are a commercial enterprise, at least in North America. They are economically sponsored. Those who sponsor the media want to sell a product. Ultimately psychographs determine what will be shown, heard or written about. Moreover, the ratings and the circulation figures will determine whether something continues to be shown, heard or written about.

Because they have an undue monopoly on the flow of information, the mass communication media are frequently involved in debates about freedom of expression, of publication, and of the press over against prior restraint, or prepublication censorship based on what is acceptable to the public. On the one hand the mass communication media are required to refrain from creating sedition, from libel and from slander, and in addition they must be objective in their reporting. On the other hand there is the public's right to know and the need, for example, for the media to be the fourth estate, i.e. to be a check on, a watchdog of, and an adversary with respect to government. Again, this does not give the media a license to publish anything. The private lives of public figures, be they politicians, movie stars, the victims or the accused of crimes must be protected. Where to draw the limits is, however, often not an easy matter to decide.

\section{Some suggestions of a Christian response to mass communication media}

From the foregoing it will be clear that mass media communication is by nature linear and monological rather than dialogic or interactive. Most of the people involved in mass media communication are recipients of its messages. They do not send messages, they can only respond to the messages they receive. They are like ethnic minorities in a majority culture. The chances are higher that they assimilate the messages of the mass media communication than that the latter should change its messages to suite its recipients. The influence of the mass media communication is currently pervasive in our lives. It is an intrusive influence and its messages are by now embedded in our very souls. How should Christians respond to this influence? 
We can reject the media. This is the way of the Amish. These Christians have banished all forms of modern communication from their communities. The result, however, is cultural isolation.

We can also accommodate ourselves to them. This approach uses the media for Christian purposes, e.g. televangelism. The problem with this approach is that it leaves the media as such largely untouched. This way of relating to the media also means that the gospel will have to be accommodated to the media.

My preferred response is that we transform or reform the media. This approach is taken by Christians who study and critique the existing media, who produce healing alternatives to them, and who support people who do this reforming work for a living.

\section{Current model of communication: social networking}

An entirely new form of communication, called social networking (Pew Research Center, 2010:32-43) is currently becoming popular, especially among young people.

Supported by a vast array of computer information and communication technologies such as e-mail, mobile phones, google, skype, facebook, myspace, blogging, twitter, and YouTube this form of communication represents a revolution in mass communication practices. It is an inherently interactive form of communication and it gives consumers a much greater freedom of choice to express their individual preferences about what is offered than was possible with earlier information and communication technologies like television, print and other visual or auditory media.

More than ever before expressions of personal preference are beginning to dictate what is offered in the traditional media as news, entertainment, consumer products and even truth. Consumers are continually contacted and consulted about their views on these matters, and they readily voice their opinions about the value of whatever is being offered. Moreover, they do so communally. Via blogging they band themselves together into virtual communities of preference. This goes so far as that the truth or value of any issue debated in the public domain is now no longer decided by some socially accepted external criterion but is entirely determined by the number of individual expressions of preference. Moreover, people are spending a considerable amount of their time online each day informing one another about their preferences and their opinions. 
This form of communication is too recent a phenomenon for anyone to be able to properly reflect on it and do justice to it. A few remarks in closing will have to suffice. The model of communication that best fits social networking is the interpersonal relations model, and like this model, it has its strengths and its weaknesses. It certainly has increased the frequency with which people personally relate to one another albeit online rather than face to face. But one gets the impression that the communicating that occurs does not go beyond an exchange of personal opinions and preferences. At its best, therefore, social networking produces only interviews between the communicators. Social networkers tend to have an aversion longer lasting social institutions. It is doubtful, therefore, whether real contact is ever made between the communicators or that something common is created like a revision of a societal structure via social networking. Thus, it falls short of meeting the criteria we set out for communication at the beginning of this article as the activity of community building.

\section{List of references}

BUBER, M. 1955. Between man and man. Boston: Beacon Paperback.

BUBER, M. 1958. I and Thou. New York: Scribner's.

CAREY, J. 1989. Communication as culture. New York: Routledge.

DOOYEWEERD, H. 1953. A new critique of theoretical thought. 4 vols. Amsterdam: Paris.

HABERMAS, J. 1981. The theory of communicative action. Boston: Beacon

MATSON, F.W. 1967. The human dialogue: perspectives on communication. New York: The Free Press.

PEW RESEARCH CENTER. 2010. The millenials: confident, connected, open to change. p. 32-43. www.pewresearch.org/millenials Date of access: 24 Feb. 2010.

ROGERS, C. 1961. On becoming a person. Boston: Houghton Mifflin.

SHANNON, C. \& WEAVER, W. 1949. The mathematical theory of communication. Urbana: University of Illinois Press.

VERBURG, P.A. 1951. Enkele lijnen en feiten in de ontwikkeling der taaltheorie. (In Zuidema, S.U., red. Wetenschappelijke bijdragen door leerlingen van Dr. D.H. Th. Vollenhoven. Franeker: Wever. p. 13-22.)

VERBURG, P.A. 1965. Delosis and clarity. (In Fortman, W.F., De Gaay, H.H.J., Dengerink, J.D., Langemeijer, G.E., Mekkes, J.P.A., Van Peursen, C.A. \& Stellingwerff, J., eds. Philosophy and Christianity: philosophical essays dedicated to Prof. Dr. H. Dooyeweerd. Kampen: Kok. p. 78-99.)

VERBURG, P.A. 1971. De mens in de taalkunde. (In Truth and reality: philosophical perspectives on reality dedicated to Prof. H.G. Stoker. Braamfontein: De Jong. p. 262-282.)

WIENER, N. 1950. The human use of human beings. Boston: Houghton Mifflin.

WIENER, N. 1961. Cybernetics or control and communication in the animal and the machine. 2nd ed. Cambridge: MIT. 


\section{Key concepts:}

communication models

community building

dialogue

monologue

social networking

\section{Kernbegrippe:}

dialogue

gemeenskapsbou

kommunikasiemodelle

monoloog

sosiale netwerking 